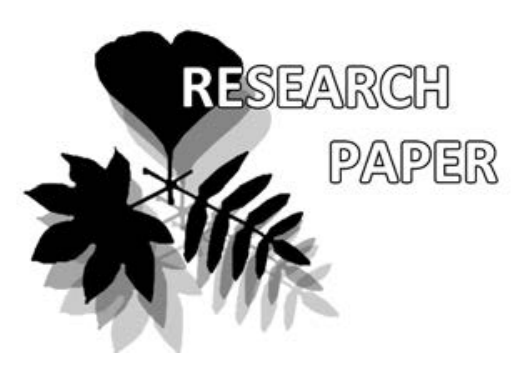

\title{
A mixotrophy is in question: new data on fungal community associated with photosynthetic terrestrial orchid Goodyera repens
}

\author{
Elena Yu. Voronina ${ }^{1 *}$, Ekaterina F. Malysheva ${ }^{2}$, \\ Vera F. Malysheva ${ }^{2}$, Georgy V. Dmitriev ${ }^{1}$, Alexei V. Tiunov ${ }^{3}$ \\ \& Alexander E. Kovalenko ${ }^{2}$
}

\author{
Elena Yu. Voronina ${ }^{1 *}$ \\ e-mail: mvsadnik@list.ru \\ Ekaterina F. Malysheva ${ }^{2}$ \\ e-mail: e_malysheva@binran.ru \\ Vera F. Malysheva ${ }^{2}$ \\ e-mail: v_malysheva@binran.ru \\ Georgy V. Dmitriev ${ }^{1}$ \\ e-mail: go.dmit@mail.ru \\ Alexei V. Tiunov ${ }^{3}$ \\ e-mail: a_tiunov@mail.ru \\ Alexander E. Kovalenko ${ }^{2}$ \\ e-mail: alkov@binran.ru
}

${ }^{1}$ Lomonosov Moscow State University, Moscow, Russia

${ }^{2}$ V.L. Komarov Botanical Institute RAS, Saint-Petersburg, Russia

${ }^{3}$ A.N. Severtsov Institute of Ecology and Evolution RAS, Moscow, Russia

* corresponding authors

Manuscript received: 08.04 .2018

Review completed: 24.04.2018

Accepted for publication: 25.04.2018

Published online: 26.04.2018

\begin{abstract}
A B S T R A C T
The boreal green orchid Goodyera repens is an object of debates on its mycorrhizal symbionts' diversity and nutritional strategy. The study was focused on biodiversity of $G$. repens mycobionts and root fungal endophytes diversity revealing by direct molecular identification from roots and rhizomes and estimation of its possible partial heterotrophy by ${ }^{13} \mathrm{C} /{ }^{15} \mathrm{~N}$ stable isotope analysis. Thirteen fungal taxa, predominantly basidiomycetes, both saprotrophs and ectomycorrhizal were detected, and the shared with coniferous tree mycobiont (Russula vinosa) was revealed both in orchid and neighbouring trees roots. The presence of wood and litter decay fungi can indicate the first steps $G$. repens on mycoheterotrophic pathway. ${ }^{13} \mathrm{C}$ depletion along with ${ }^{15} \mathrm{~N}$ enrichment characterizes $G$. repens as initially mycoheterotrophic-autotrophic species. The similarity of $\delta^{15} \mathrm{~N}$ values with litter saprotroph fungi both with sharp increase in ${ }^{13} \mathrm{C} /{ }^{15} \mathrm{~N}$ in underground parts need further investigation with particular attention to clonal growth and intraclonal transfer potential and mycobiont diversity.
\end{abstract}

K e yw ord s : Orchidaceae, mycorrhizal symbionts, root endophytes, fungal diversity, $n r \mathrm{ITS}$, stable isotope analysis

\section{P E 3 Ю M E}

Воронина Е.Ю., Малышева Е.Ф., Малышева В.Ф., Амитриев Г.В., Тиунов А.В., Коваценко А.Е. Миксотрофность под вопросом: новые Аанные о грибном сообществе, связанном с фотосинтезирующей наземной орхидеей Goodyera repens. Объектом исследования является Goodyera repens, бореальный хлорофимл-содержащий виА орхилных, чьё разнообразие микоризных симбиионтов и трофический статус Аискуссионны. Целью исследования было выявление биоразнообразия грибов-микобионтов и корневых эндофитов $G$. repens посредством прямого молекулярного анализа корней и корневищ, а также установление возможной частичной гетеротрофии растения с помощью анализа стабильных изотопов $\left({ }^{13} \mathrm{C} /{ }^{15} \mathrm{~N}\right)$. Выяв ено 13 таксонов грибов, в основном, базидиомицетов, относящихся как к сапротрофам, так и к эктомикоризообразователям, и обнаружен общий с хвойными Аревесными породами симбионт Russula vinosa. Присутствие в корневой системе $G$. repens подстилочных и ксилосапротрофов может указывать на первые шаги вида в эволюции микогетеротрофии. Обеднение по ${ }^{13} \mathrm{C}$ наряду с обогащением по ${ }^{15} \mathrm{~N}$ характеризует $G$. repens как изначально микогетеротрофный, впослеАствии автотрофный виА, но схоАство значений $\delta^{15} \mathrm{~N}$ с грибами - подстилочными сапротрофами, а также резкое повышение содержания ${ }^{13} \mathrm{C} /{ }^{15} \mathrm{~N}$ в подземной части растений требует Аальнейшего изучения. Особого внимания заслуживают клональный poct $G$. repens, подразумевающий возможность транспорта питания внутри колонии, и разнообразие микобионтов.

КАючевые слова: Orchidaceae, микоризные симбионты, эндофиты, разнообразие грибов, $n$ ITS, анализ стабильных изотопов
The plant family Orchidaceae containing about 30000 species is one of the largest and the most diverse families of the plant kingdom (Tsai et al. 2017). The impressive variety and distribution of orchids may be due to the fact that the plants produce a huge amount of dust-like seeds carried by the wind (Arditti \& Ghani 2000). Species of Orchidaceae are known for ultimate dependence on their fungal partners under natural conditions, especially while their minute seeds germinate. All Orchidaceae species are mycoheterotrophic at early (often rather prolonged, up to several years long) stages of the life cycle i.e. gain their carbon nutrition from their fungal symbionts. Adult plant individuals from some species switch to autotrophic nutrition mode whilst others keep full dependence on their mycobionts through all lifespan and lack the ability to photosynthesize (Leake 1994, Smith \& Read 2008). It was recently shown that some or- 
chid species associated with ectomycorrhizal fungi are mixotrophic or partial myco-heterotrophic and are capable of gaining additional carbon from fungal partner along with photosynthetic assimilation retaining (Julou et al. 2005).

A mycorrhiza of orchids is unique in that it occurs exclusively within the family Orchidaceae (Rasmussen 1995, Peterson et al. 1998). Besides the mycobionts forming intracellular symbiotic interface within root cells, hyphal coils known as pelotons, orchids harbour a plethora of fungal root endophytes, sometimes referred as RAF (root-associated fungi), showing no specific intraradical structures (Bayman \& Otero 2006, Kohout et al. 2013). The interactions of such fungi with host plants are mostly unrevealed, but there are some reports on their plant-beneficial role due to activity against phytopathogenic microfungi and bacteria (Chen et al. 2012, Zhao et al. 2014). Another unique feature of orchid mycorrhiza is that despite of the complicated symbiotic contact zone and fine-tuned interactions between partners, there are no particular "orchid mycorrhizal fungi" at all. Orchids recruit a wide range of Asco- and Basidiomycota fungi belonging to saprotrophs on litter, soil and wood, ectomycorrhizal symbionts and even plant pathogens deleterious for non-orchid plants (Dearnaley et al. 2012). Ceratobasidium species commonly reported from a wide range of orchid species worldwide can provide an excellent example. These fungi can perform as saprotrophs, plant pathogens and were even revealed as ectomycorrhizal in the Australian shrub Melaleuca (Smith \& Read 2008, Bougoure et al. 2010, Mosquera-Espinosa et al. 2013).

Despite the fact that the relationship between a fungus and a host in the case of green plants (including orchids) mycorrhizas is usually regarded as mutualistic, before Cameron et al.'s work (Cameron et al. 2006, 2007, 2008) it was not experimentally demonstrated for certain whether the mycobiont is actually benefited from such symbiosis in the terms of carbon gain. These recent studies on Goodyera repens (L.) R. Br. and its mycorrhizal symbiont Ceratobasidium cornigerum (Bourdot) D.P. Rogers provided some evidence that orchid species, being photosynthetically active, can transfer carbon back to fungus (although in fact this carbon flow was a fairly small $-0.4-3.0 \%$ ). Nevertheless, the mutualistic relationship between $G$. repens and fungi associated with this green orchid still remains a debated issue that needs further study (Smith \& Read 2008). The most recent research based on stable isotope natural abundance analysis showed that $G$. repens cannot compensate for its resource constraints of $\mathrm{N}$ and $\mathrm{C}$ by using ${ }^{13} \mathrm{C}$ - and ${ }^{15} \mathrm{~N}$-enriched fungal source, and nutrient flux from fungal partners does not correlated at all with intensity of insolation (Liebel et al. 2015). It was suggested that growth features such as long rhizomes on which numerous photosynthetic rosettes are produced is the only way for $G$. repens to adapt to shaded conditions. However, the same isotopic analysis showed obvious and significant depletion of leaf ${ }^{13} \mathrm{C}$ value compared with surrounding autotrophic plants (Hynson et al. 2009), and this fact hitherto has no reasonable explanation. Thus, available data is still insufficient to speak clearly about the trophic strategy of green orchids from the tribes Orchideae and Cranichideae, including G. repens. It should be said that all methods applied for evaluation of the role of mycorrhiza in adult green orchids were not without flaws. The substantive conclusions on trophic strategy of green orchids were based on isotopic method, though it is known about its ability to overestimate or underestimate an autotrophy level of a studied plant. Because of that some species with "normal" ${ }^{13} \mathrm{C}$ abundance may represent with a certain probability so-called "cryptic" mixotrophs, undetectable by isotopic methods (Selosse et al. 2017). Recently Gebauer et al. (2016) presented a new isotopic approach for plant partial mycoheterotrophy measurement, namely, to use ${ }^{2} \mathrm{H} /{ }^{18} \mathrm{O}$ pair for its estimation and thus detected far more widespread partial mycoheterotrophy in green orchids than it was previously thought, but experimental data were obtained for rather few species yet to make any generalizations.

We still also lack information on a precise range of fungal partners associated with these plants. An indisputable fact is the dependence of orchid protocorms on their fungi, but the relationship between adult individual and its fungi is less clear and evidently highly versatile. Evidence from some studies supports the hypothesis that the nature of relationship between orchids and their fungal partners may even be a parasitism, where the plant parasitizes on its mycobiont (Peterson et al. 2004).

It is now generally known that roots of many photosynthetic adult terrestrial orchids are constantly colonized by specific groups of fungi (Zelmer et al. 1996, Rasmussen \& Whigham 2002), representing a potentially substantial source of carbon and other nutrients. The most common mycobionts forming mycorrhiza with orchid species are fungi of the polyphyletic rhizoctonia group (usually from families Tulasnellaceae, Ceratobasidiaceae and Sebacinaceae). Species with photosynthetic ability are generally associated with a wider range of mycobionts compared with mycoheterotrophic species (Rasmussen 2002). Recently it was established due to molecular techniques that ectomycorrhizal fungi can sporadically colonize the root of green orchids (Liebel et al. 2015), besides some green orchids, even in different habitats, are able to associate with only one fungus at a time (Shefferson et al. 2005, McCormick et al. 2006). It is conceivable that the specificity of such mycorrhizal link with a single partner probably leads to a more effective physiological association that is important for species living in shaded habitats (Girlanda et al. 2006), though the direct evidences of benefits for plants from such a strict specificity are absent.

Goodyera repens is a green perennial shrub typical for boreal zone, having a cord-like horizontally spreading creeping rhizome, with a few lateral roots located in the forest litter. The species belong to so called clonal plants, forming colonies interconnected by creeping rhizomes. It commonly grows in shaded coniferous, mixed or small-leaved forests, preferring moderately wet places (Rasmussen 1995). The diversity of mycorrhizal partners as well as root fungal endophytes is still poorly investigated for this species. The nutrition strategy of this orchid in its adulthood also remains to be determined. Lately, more new data on ectomycorrhizal abilities of many $G$. repens fungal symbionts are 
beginning to accumulate. Besides typical ectomycorrhizal taxa, such as Lactarius, Russula and Sebacina, it became known about ectomycorrhizal habits of some"rhizoctonia" lineages (Bougoure et al. 2010, Yagame et al. 2012) forming associations with Goodyera species.

In the present study we explored populations of G. repens growing under natural conditions in wet mossy coniferous forests with some deciduous tree species. We aimed to determine the diversity of fungi obtained from root and rhizomes of the orchid and to compare it with that in ectomycorrhizal roots tips of surrounding trees by direct sequencing of fungal ITS amplicons. We specifically hypothesized that, the discovery of any indirect connection of adult individuals of G. repens with surrounding trees through the same fungal symbionts may support an assumption of mixotrophy nutrition strategy of the studied orchid species. We also used stable isotope analysis to test our assumptions.

\section{MATERIAL AND METHODS}

\section{Study site and sampling scheme}

Sampling was conducted in 2016 twice a season at two sample plots $(50 \times 50 \mathrm{~m})$ in coniferous forests in the Moscow Region (Table 1). Goodyera repens individuals representing a range of different life stages were chosen. From each target population at least three-four plants were collected at a wide distance between. The plant samples were carefully wrapped with polyethylene film or aluminum foil and placed into sealed plastic bags for transporting to the laboratory. Before processing samples were stored at $4^{\circ} \mathrm{C}$. In the laboratory, they were thoroughly washed with tap water. From each orchid individual collected roots as well as rhizomes were selected for further molecular analysis, and vegetative parts (basal and apical leaves) were sampled for assessment of ${ }^{13} \mathrm{C}$ and ${ }^{15} \mathrm{~N}$ stable isotope abundance. In total, 36 plant individuals were sampled (root and rhizome samples and a matching sample of leaves per plant were collected).

At each sample plot roots of surrounding trees at the depth of $G$. repens underground part and in its close proximity were additionally sampled. Sometimes common mycelial networks shared by orchid and tree roots were visually detected. Only coniferous root tips were revealed near $G$. repens despite of deciduous trees presence at sample plots. As the roots were released from soil with running water, they were examined under a binocular microscope in order to check tips for EcM mantle presence.

Individual root tips and segments of rhizomes from single $G$. repens plants that appeared to be colonized by fungi as well as ectomycorrhizal root tips from trees were placed in $2 \%$ cetyltrimethylammonium bromide (CTAB) buffer in $1.5 \mathrm{ml}$ tubes for further analysis.

For obtaining matches and reference material for isotope signatures of studied plants, the litter and upper organic soil horizon were sampled (10 soil and corresponding litter samples per plot) along with macrofungal fruitbodies of bryophiles, litter and soil saprotrophic and ectomycorrhizal species. In total 30 fungal species (Agaricomycetes: Agaricales, Cantharellales, Russulales) were analyzed. To compare ${ }^{13} \mathrm{C}$ and ${ }^{15} \mathrm{~N}$ abundance in G. repens to plants of putatively different nutrition strategy leaves from arbutoid mycorrhizal (ArM - 4 species), ericoid mycorrhizal (ErM - 2), ectomycorrhizal (EcM - 7) and 32 arbuscular mycorrhizal coupled with non-mycorrhizal (AM/NM) reference species were collected. The last group was not further separated into AM and NM due to known facultative character of their mycorrhizal colonization. Only vascular plants were used as references. The information on plants mycorrhizal status is provided according to Harley \& Harley (1987). Samples for further ${ }^{13} \mathrm{C}$ and ${ }^{15} \mathrm{~N}$ isotope analysis were proceeded by drying at $50^{\circ} \mathrm{C}$ till air-dry condition.

\section{Molecular identification of mycorrhizal and endophytic fungi}

TDNA was extracted from G. repens roots and rhizomes and ectomycorrhizal tips using the Nucleo-Spin Plant II Kit (Macherey-Nagel GmbH \& Co. KG), according to the manufacturer's instructions. The fungal ITS region (ITS1-5.8SITS2) was amplified using two sets of primers: ITS1F + ITS4 and ITS1F + ITS4B (Gardes \& Bruns 1993, White et al. 1990). Successful amplifications confirmed visually with agarose gel electrophoresis were then cleaned using the GeneJET PCR Purification Kit (Thermo Scientific, Thermo Fisher Scientific Inc., MA, USA) and quantified using the NanoPhotometer P-300 (Implen GmbH, Germany). In the case of two or more bands amplified, the total product was loaded on agarose gel and then each band was extracted from gel and recovered using the GeneJET Gel Extraction Kit (Thermo Scientific, Thermo Fisher Scientific Inc., MA, USA), according to the manufacturer's protocol for gel extraction. The prepared PCR product was then sequenced with the same primer pairs. DNA sequencing was performed on an ABI3130 Genetic Analyzer using BigDye ver. 3.1 chemistry (Applied Biosystems, Foster City, CA, USA). Electrophoretograms were checked using Sequencing Analysis 5.3.1 (Applied Biosystems) and MEGA 6 (Tamura et al. 2013).

All stages of molecular studies were carried out on equipment of the Center for collective use of scientific

Table 1. Sampling sites of G. repens, numbers of populations and individuals sampled, and the mycorrhizal trees present in the habitats

\begin{tabular}{llll}
\hline $\begin{array}{l}\text { Sampling } \\
\text { site }\end{array}$ & Latitude/longitude & $\begin{array}{l}\text { Dominant } \\
\text { tree species }\end{array}$ & $\begin{array}{l}\text { Other ectomycorrhizal trees in the } \\
\text { habitat }\end{array}$ \\
\hline S1 & $55^{\circ} 41.482^{\prime} \mathrm{N}, 36^{\circ} 43.102^{\prime} \mathrm{E}$ & $\begin{array}{l}\text { Picea abies } \text { (L.) H.Karst, } \\
\text { Pinus sylvestris L. }\end{array}$ & $\begin{array}{l}\text { Betula sp., Quercus robur L., Sorbus } \\
\text { aucuparia L., Tilia cordata Mill. }\end{array}$ \\
S2 & $55^{\circ} 41.690^{\prime} \mathrm{N}, 36^{\circ} 44.377^{\prime} \mathrm{E}$ & $\begin{array}{l}\text { Pinus sylvestris L., Picea abies } \\
\text { (L.) H.Karst, Betula sp., }\end{array}$ & $\begin{array}{l}\text { Populus tremula L, Quercus robur L., } \\
\text { Sorbus aucuparia L., Tilia cordata Mill. }\end{array}$ \\
\hline
\end{tabular}


equipment "Cellular and molecular technology of studying plants and fungi" at the Komarov Botanical Institute of the Russian Academy of Sciences.

Obtained sequences with high quality and degree of similarity (cutoff of $97 \%$ ) were clustered into groups and were manually processing and optimized using the MEGA 6. Chimeric sequences assessed by reference-based checking using GenBank were removed from further analyses. We regarded a sequence as a chimera when its ITS1 and ITS2 regions had $98-100 \%$ similarity to different species or $>90 \%$ similarity to different genera. The remaining consensus sequences were then analyzed to ascertain taxonomic affinity. Identification of "Operational Taxonomic Units" (OTUs) was based on the BLASTn search algorithm in NCBI GenBank (http://www.ncbi.nlm.nih.gov/ genbank/) or UNITE sequence databases (http://unite. ut.ee/, Kõljalg et al. 2005). The degree of similarity was accepted: for species level $\geq 97 \%$ (Kõljalg et al. 2013, Smith et al. 2013), for genus level $95-97 \%$ and for family to order level $<95 \%$. When two or more sequences or sequence groups differed to each other but matched the same entry in databases, a number was added to the name to mark the differences (e.g. Tomentella sp. 1 and Tomentella sp. 2). A list with the taxa names and the accession numbers of the corresponding database entry of the best match is given in Table 2. All newly generated sequences have been deposited in GenBank with corresponding accession numbers.

\section{Stable isotope analysis}

Previously dried samples were pulverized with ball grinder Retsch MM200 (90 s with 19 per s cycles frequency) and further oven-dried at $50^{\circ} \mathrm{C}$. Then the scaled probes (with $1 \mathrm{mkg}$ precision) were put into tin capsules and ${ }^{13} \mathrm{C}$ and ${ }^{15} \mathrm{~N}$ isotope abundance was analyzed with isotope mass spectrometer Thermo-Finnigan Delta V Plus and elemental analyzer Thermo Flash 1112. Relative isotope abundances are indicated as $\delta$ values.

The raw data on $\delta^{13} \mathrm{C}$ and $\delta^{15} \mathrm{~N}$ values was proceeded in Statistica 7.0 program package. They are presented in the form of mean value $\pm 1 \mathrm{SD}$ (standard deviation). The nonparametric criteria were used for verification of significant differences: Mann-Whitney U test for comparison between a pair of samples and Kruskal-Wallis $\mathrm{H}$ test for multiple comparisons. The difference was presumed significant at p-level $<0.05$. Boxplots were arranged from the mean values with SE (standard error) and SD interval bars.

\section{R E S U LT S}

\section{Fungal diversity associated with $G$. repens roots and rhizomes}

Fungal nrITS were amplified from about 60 root pieces of $G$. repens and 40 ectomycorrhizal root tips of neighbouring trees, and more than $30 \%$ consisted in multiple PCR fragments. In total, 45 fungal $n r$ ITS sequences were obtained, among which 24 were grouped into phylogenetic lineages or OTUs. All sequenced fungi belonged to ascoand basidiomycetes. The majority of the fungi detected originated from roots of neighbouring trees. In contrast, only a few positive amplifications were obtained from or- chid samples. Sequences obtained from $G$. repens roots were predominantly assigned to Thelephorales. The other most common fungal groups were Polyporales, Glomerellales and Russulales, whereas sequences of "rhizoctonia" fungi in our study were sporadically retrieved from roots of $G$. repens as Ceratobasidium and Tulasnella species found in plants from both study sites (Table 2).

Based on the ecology of their closest GenBank relatives, at least 11 out of 24 sequences belong to obligate ectomycorrhizal basidiomycetes (Table 2), others are from possibly saprotrophs and plant endophytes (RAF). Notably, sequences assigned to Russula vinosa Lindblad were obtained from both orchid and trees that may indicate the formation of a single EcM network involving surrounding trees. Underground organs of G. repens in habitats studied are located in litter or in the uppermost soil layer and nearly always surrounded by tree (as a rule, conifer) ectomycorrhizal tips. Sometimes the orchid and tree are interconnected by mycelial strands visible with the naked eye. For such spruce and pine tree mycorrhizal tips the mycobiont shared with G. repens (Russula vinosa) was revealed. Ectomycorrhizal Russula previously was only once mentioned as symbiont for G. repens (Liebel et al. 2015). Species of this genus are widely acknowledged, often high-specialized mycobionts of full and partial heterotrophic Ericaceae and Orchidaceae plants (Smith \& Read 2008).

\section{Carbon and nitrogen isotopic abundances in G. repens}

The common approach to assess the level of heterotrophy in plants is estimation of ${ }^{13} \mathrm{C}$ and ${ }^{15} \mathrm{~N}$ enrichment in heterotrophs compared to autotrophs (Selosse \& Roy 2009). $\delta^{13} \mathrm{C}$ and $\delta^{15} \mathrm{~N}$ values for $G$. repens varied widely from -38.87 to $-24.46 \%$ for ${ }^{13} \mathrm{C}$ (with mean values $-34.96 \pm 3.15 \%$ o and $-35.26 \pm 1.56 \%$ for S1 and S2 correspondingly) and from -6.44 to $-2.12 \%$ for ${ }^{15} \mathrm{~N}$ (with mean values $-4.29 \pm$ $1.1 \%$ and $-5.33 \pm 0.54 \% 0) . \delta^{13} \mathrm{C}$ values demonstrated no significant difference between sampling sites $(\mathrm{U}=585, \mathrm{p}$ $=0.93)$ and $\delta^{15} \mathrm{~N}$ values were significantly lower for S2 (U $=251, \mathrm{p}<0.001) \cdot \delta^{13} \mathrm{C}$ and $\delta^{15} \mathrm{~N}$ values for litter and the uppermost organic soil horizon (the zone where $G$. repens root system is located) showed rather high similarity between sampling sites (Table 3) and no correlation between the target plant signatures and the corresponding substrate variables was detected.

The fungal $\delta^{13} \mathrm{C}$ and $\delta^{15} \mathrm{~N}$ values compared between the fungal guilds and to G. repens are given in Table 4. The $\delta^{15} \mathrm{~N}$ values are highly variable, but both types of variables and their relations are in line with data published (Rinaldi et al. 2008, Agerer et al. 2012). Compared to G. repens, all fungal guilds examined were enriched in $\delta^{13} \mathrm{C}$, a trait common for green plants not necessarily coinciding with autotrophy (Gebauer et al. 2016). $\delta^{15} \mathrm{~N}$ values of $G$. repens were close to those of litter saprotrophs, but the variation of values was extremely large both for the target plant and all fungi examined. The further discussion of G. repens vs fungal isotopic signatures is restricted by surprisingly low intersection between above-ground (according to fruitbody survey) and below-ground (according to direct molecular approach) parts of fungal community. From all fungal species detec- 


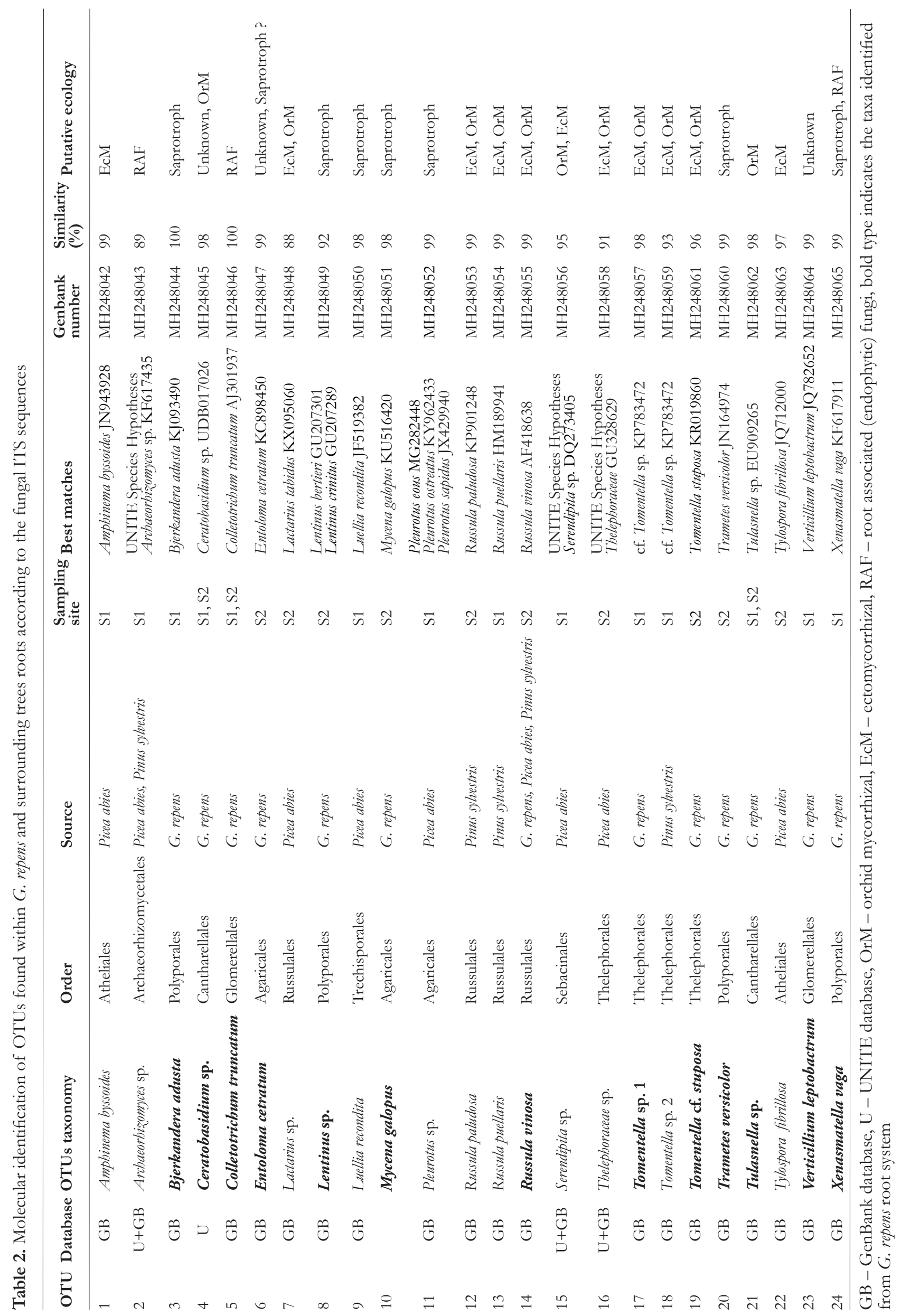


Table 3. $\delta^{13} \mathrm{C}$ and $\delta^{15} \mathrm{~N}$ values for litter and the uppermost soil horizons on sample sites

\begin{tabular}{lcccc}
\hline Sampling site & \multicolumn{2}{c}{$\boldsymbol{\delta}^{\mathbf{1 3} \mathbf{C}, \boldsymbol{\%} \mathbf{0}}$} & \multicolumn{2}{c}{$\boldsymbol{1}^{\mathbf{1 5} \mathbf{N}, \boldsymbol{\%} \mathbf{0}}$} \\
\cline { 2 - 5 } & Litter & Soil & Litter & Soil \\
\hline S1 & $-28.7 \pm 0.87$ & $-27.84 \pm 0.53$ & $-4.21 \pm 0.69$ & $-4.0 \pm 0.7$ \\
S2 & $-29.45 \pm 0.94$ & $-28.66 \pm 0.47$ & $-3.81 \pm 0.42$ & $-4.2 \pm 1.1$ \\
Mean for both sites & $-29.05 \pm 0.96$ & $-28.25 \pm 0.64$ & $-4.02 \pm 0.6-$ & $-4.1 \pm 0.88$ \\
Significance of differences between sites & $\mathrm{U}=28$ & $\mathrm{U}=\mathbf{1 3}$ & $\mathrm{U}=31$ & $\mathrm{U}=45$ \\
& $\mathrm{p}=0.17$ & $\mathrm{p}<\mathbf{0 . 0 5}$ & $\mathrm{p}=0.25$ & $\mathrm{p}=0.38$ \\
\hline
\end{tabular}

Bold type indicates significant differences $(\mathrm{U}$ test, $\mathrm{p}<0.05)$

ted in both tree and orchid roots only Mycena galopus (Pers.) P. Kumm. (probably, rather RAF than true mycobiont) was detected at the fruitbody stage. However, the fact of similarity between $\delta^{15} \mathrm{~N}$ values of the plant and litter saprotrophic fungi deserves attention in the light of data on their probable associations (Selosse et al. 2010).

The comparison of G. repens $\delta^{13} \mathrm{C}$ and $\delta^{15} \mathrm{~N}$ values with those for reference plants with putatively different nutrition strategy (ArM, ErM, EcM and AM/NM) showed the pattern similar to revealed by other researchers (e.g. Hynson et al. 2009, Liebel et al. 2015). The data is presented for S1 (Fig. 1), for S2 lacks arbutoid mycorrhizal pyroloid plants. The mean $\delta^{13} \mathrm{C}$ values for ArM plants are $-33.57 \pm 0.73 \%$, for ErM $-35.47 \pm 0.45 \%$, for EcM $-34.12 \pm 1.0 \% 0$ and for AM/NM-34.15 $\pm 1.63 \%$. The corresponding values of $\delta^{15} \mathrm{~N}$ are: $-2.5 \pm 1.01 \% 0,-5.39 \pm 0.29 \% 0,-4.9 \pm 1.36 \% 0$ and $-4.95 \pm 1.4 \%$. The main tendency in $\delta^{13} \mathrm{C}$ values was $G$. repens depletion with the difference significant comparing to ArM only $(\mathrm{H}=17.25, \mathrm{p}=0.0017) \cdot \delta^{15} \mathrm{~N}$ values of G. repens significantly distinguished only from ArM too $(\mathrm{H}$ $=39.05, \mathrm{p}<0.0001)$. Here we observed an opposite tendency for enrichment in the target plant and this pattern for both variables is consistent with reported by Hynson et al. (2009). The ArM plants (Orthilia secunda (L.) House and Pyrola spp.) demonstrated enrichment both in $\delta^{13} \mathrm{C}$ and $\delta^{15} \mathrm{~N}$ compared to other plant groups which can mirror partial mycoheterotrophy of pyroloids considered inconsistent and habitat-dependent (see Hynson et al. 2013), but previously shown for the same sites by Malysheva et al. (2017). The reason for $\delta^{13} \mathrm{C}$ depletion in G. repens compared to true autotrophic non-orchid plants is hard to explain, but it can result from the mycorrhizal associations with particular fungal partners, as it was suggested by Hynson et al. 2013 and Selosse et al. 2017. Unfortunately, the data obtained was insufficient for statistic-based comparison of $\delta^{13} \mathrm{C}$ and $\delta^{15} \mathrm{~N}$ values for G. repens associated with ectomycorrhizal vs saprotrophic fungi, because the nutritional mode of mycobiont can influence isotopic content of a plant (Gebauer et al. 2016). The G. repens tendency to enrichment in $\delta^{15} \mathrm{~N}$ compared to EcM plants is very important for this element is currently presumed to be very important in the displaying of partial heterotrophy (Schiebold et al. 2017).

The significantly higher $\delta^{13} \mathrm{C}$ values (more than $-28 \%$ ) close to those for saprobic fungi were observed for young plants' upper parts of green shoots. The delimitation between green shoot and rhizome is quite obscure in the case of G. repens, so the distinction found can presumably reflect the different $C$ sources for different plant organs. The rhizome and young shoots contain mycobiont-derived C, whereas leaves have predominantly photosynthetic products. The typical for $G$. repens clonal life-style can influence mixotrophy quantitative parameters too. A shoot analyzed can receive its organic matter via rhizomes from another part of the clone, from shoots existing in somewhat different microhabitats (Selosse et al. 2017). There was rather pronounced variation in $\delta^{13} \mathrm{C}$ (from -35.7 till $-24.5 \%$ ) and $\delta^{15} \mathrm{~N}$ (from -5.4 till $-3.5 \%$ ) detected within a single G. repens clone explored. The revealing of the potential heterogeneity of mycobionts within clonal plants populations and different factors relative impact can help to estimate the different C sources contribution to mixotrophic plants performance.

\section{DISCUSSION \\ Fungal partners}

As a result of our study, 13 mycobionts and root fungal endophyte taxa (of species and genera level) were detected in G. repens root and rhizomes.

Orchid mycorrhiza engages fungi with different ecological strategies, such as saprobes, ectomycorrhizal symbionts and plant pathogens (for non-orchid plants). Ecological traits of these fungi and its nutrition strategies are often obscure (Smith \& Read 2008). Ceratobasidium species was detected repeatedly using $n r$ ITS sequencing from plant root tissues. Species of this genus, especially C. cornigerum, are often reported from orchid (including G. repens) mycorrhizas worldwide. Ceratobasidium species are predominantly saprobic, some endophytes and facultative pathogens of nonorchid plants are known within them (Currah \& Zelmer 1992). However, EcM-forming ability was lately pointed out in some Ceratobasidiaceae including C. cornigerum (Bougoure et al. 2010, Yagame et al. 2012). This fact is crucial for debunking of a long-lasting bias of "rhizoctonia"-fungi (including Ceratobasidiaceae) exceptional association with green adult-autotrophic orchids contrary to mycoheterotrophic ones restricted to EcM mycobionts (see in Smith \& Read 2008). After the tripartite symbiosis between autotrophic shrub Melaleuca, fully heterotrophic orchid Rhizanthella and Ceratobasidium was discovered (Bougoure et al. 2010), it became obvious that "rhizoctonias" had a potential for common networks shared by orchids and thus facilitate transfer between auto- and heterotrophic plants. Moreover, the current opinion on green orchids mycorrhizal with "rhi- 

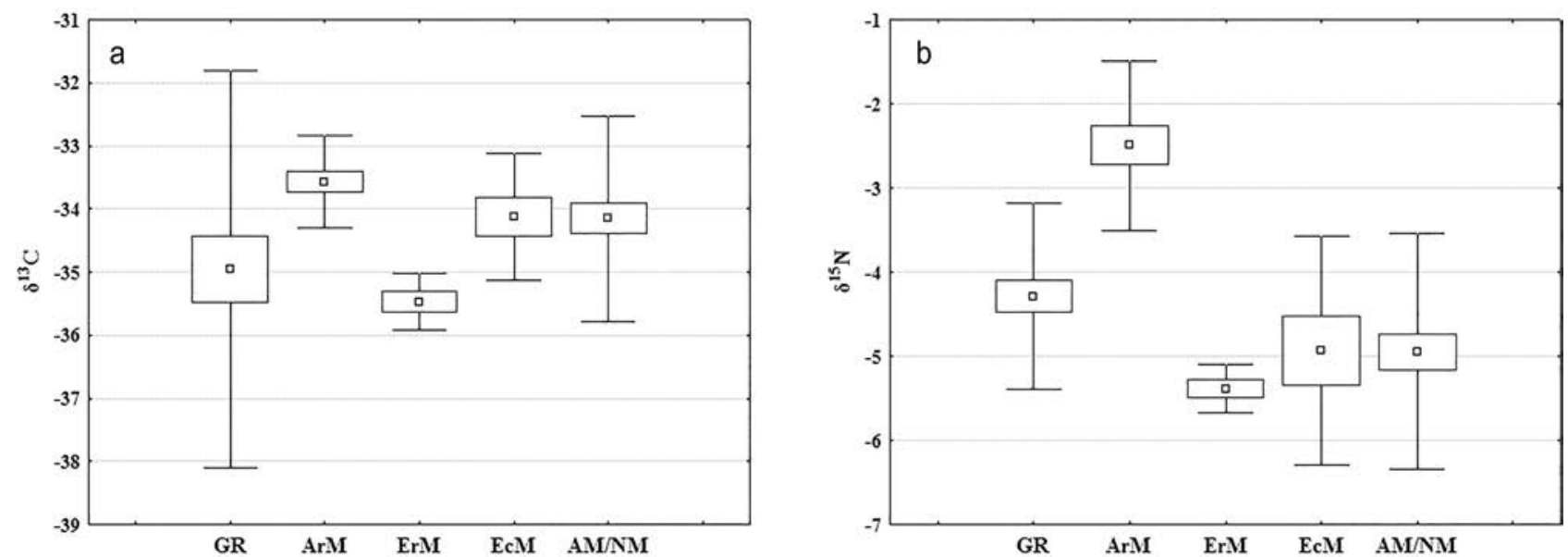

Figure $1 \delta^{13} \mathrm{C}$ (a) and $\delta^{15} \mathrm{~N}$ (b) values of Goodyera repens in comparison with other plant groups. Absciss axis: GR - Goodyera repens, reference plants: ArM - arbutoid mycorrhizal, ErM - ericoid mycorrhizal, EcM - ectomycorrhizal, AM/NM - arbuscular and non-mycorrhizal. Ordinate axis: $\delta^{13} \mathrm{C}, \%$ (a), $\delta^{15} \mathrm{~N}, \%$ (b). Boxplot: mean value as central marker, with mean \pm SE as box and mean \pm SD as whiskers

zoctonias" claims their 'predisposition' to mycoheterotrophy 'due to their initially mycoheterotrophic seedling stage' (Selosse et al. 2017, Schweiger et al. 2018).

Colletotrichum species were among the common fungal endophytes in G. repens roots and rhizomes. These fungi are known as different tropical epiphytic orchid species RAF (Bayman \& Otero 2006) and pathogens and endophytes in non-orchid plants. Stress-tolerance and growth promoting and productivity stimulating effects in host were shown for Colletotrichum. However, a comparison with data obtained by other researchers and estimating the intensity of the effect is impeded by relatively recent taxonomic revision of the genus and new species description (Damm et al. 2010). Suppression of both bacteria and micromycetes was shown for root endophyte fungal species of Orchidaceae. They can also contribute to host plant fitness and successful establishment of symbiotic relationships (Chen et al. 2012, Zhao et al. 2014). Another RAF species from G. repens roots, Verticillium leptobactrum, turned out to be active against plant pathogenic nematodes and possesses a high biocontrol potential for agriculture (Hajji et al. 2017). Recently the plant protective strategy of recruiting entomo- and other invertebrate pathogenic fungi as endophytes gained a lot of attention (Ownley et al. 2010), but such data on Orchidaceae are extremely scarce. Functions and ecological plasticity of orchid RAF predominantly stay still unexplored.

Notably, the vast majority of fungal species detected in the present study from G. repens root system belongs to basidiomycetes. The identified OTUs were split evenly between the two major ecological groups: saprotrophs and mutualistic symbionts involved in forming both ectomycorrhizal and orchid mycorrhizal associations (Table 2). All EcM taxa revealed in our study were similar to previously found in G. repens and other green orchids in Norway and the USA (Shefferson et al. 2005, Liebel et al. 2015). Goodyera species were shown to form mycorrhizae most frequently with the "rhizoctonias" (mainly with basidiomycete genera Ceratobasidium and Tulasnella) but occasionally and simultaneously associate with EcM fungi, including Russula spp., Lactarius spp., Sebacina spp., Thelephora spp., Cortinarius spp., Tomentella spp. and Phialophora finlandia (Shefferson et al. 2005, 2007, Lievens et al. 2010). Identical fungal ntITS sequences of Russula vinosa in orchid roots and EcM of neighbouring trees revealed by us may point to some orchid nutritional benefits from common mycorrhizal network. Thus, our observations confirm the nonrandom finding of such species in connection with the orchid indicating that this complex of fungi can support the growth of adult plants. G. repens is thus likely to be able to derive its carbon from the tree via ectomycorrhizae, exactly as described for other green mixotrophic orchids (Roy et al. 2013), as well as for species of Ericaceae (Zimmer et al. 2007). Though the possible involvement of EcM fungi in G. repens nutrition is often discussed (Liebel et al. 2015), more evidence and more accurate estimators are needed to resolve their true role in orchid performance during its life cycle.

The detection of saprotrophic fungi in G. repens root system was more unexpected than revealing EcM taxa. Most of them, viz. Xenasmatella vaga, Trametes versicolor, Lentinus sp. and Bjerkandera adusta, belong to known active wood destructors, except for Entoloma cetratum whose trophic strategy is rather uncertain and Mycena galopus known as litter saprotroph with a preference for damp mossy habitats with Sphagnum (Aronsen \& Laessoe 2016) as it was typical for S2. These fungi were found mainly at the mixed closed-canopy forest (site S2) characterized by scarce insolation. We can assume that such shaded environmental conditions can cause larger carbon requirements from orchids, and thereby encourage the plant to find more productive partners in terms of carbon gaining than non-EcM "rhizoctonias" suppliers. At present, evidence is beginning to accumulate that saprotrophic fungi, like true mycorrhizal partners, can provide advantages in nutrition to some green orchids particularly inhabiting in tropical ecosystems. This was shown for mixotrophic Cremastra appendiculata (Yagame et al. 2013) and other green "rhizoctonia"-associated orchids (Fan et al. 1996, Guo et al. 1997). There are also some studies identifying diverse saprobic fungal taxa in fully mycoheterotrophic orchids (Ogura-Tsujita \& Yukawa 2008, Selosse et al. 2010). The most stunning recent discovery in this field is the fact 
Table 4. $\delta^{13} \mathrm{C}$ and $\delta^{15} \mathrm{~N}$ values for fungal species detected on sample sites by fruitbody survey and its comparison to Goodyera repens corresponding variables

\begin{tabular}{|c|c|c|c|c|c|c|}
\hline \multirow{2}{*}{$\begin{array}{l}\text { Sampling site } \\
\text { Guilds }\end{array}$} & \multicolumn{3}{|c|}{$\delta^{13} \mathrm{C}, \%$} & \multicolumn{3}{|c|}{$\delta^{15} \mathrm{~N}, \%$} \\
\hline & S1 & S2 & $\begin{array}{c}\text { Mean for both } \\
\text { sites }\end{array}$ & S1 & S2 & $\begin{array}{c}\text { Mean for both } \\
\text { sites }\end{array}$ \\
\hline Bryophiles (Br) & - & $-21.57 \pm 0.1^{\mathrm{c}}$ & - & - & $-2.5 \pm 0.29$ & - \\
\hline Litter saprotrophs (LS) & $-24.86 \pm 1.64$ & $-23.73 \pm 1.08$ & $-24.34 \pm 1.48$ & $-4.07 \pm 0.96$ & $-2.65 \pm 1.77$ & $-3.41 \pm 1.53$ \\
\hline Soil saprotrophs (SS) & $-23.52 \pm 0.94$ & $-24.27 \pm 0.79$ & $-23.99 \pm 0.9$ & $-0.24 \pm 1.78$ & $-0.88 \pm 1.12$ & $-0.65 \pm 1.39$ \\
\hline Ectomycorrhizal (EcM) & $-25.49 \pm 1.07$ & $-26.01 \pm 1.08$ & $-25.75 \pm 1.1$ & $-1.87 \pm 1.9$ & $0.08 \pm 3.2$ & $-0.86 \pm 2.82$ \\
\hline $\begin{array}{l}\text { Significance of } \\
\text { differences between } \\
\text { guilds }\end{array}$ & $\begin{aligned} \mathrm{H} & =11.89 \\
\mathrm{p} & =0.03 \\
\mathrm{SS} & >\mathrm{EcM}\end{aligned}$ & $\begin{array}{c}\mathrm{H}=33.54 \\
\mathrm{p}<0.001 \\
\mathrm{Br}>\mathrm{EcM} \\
\mathrm{LS}>\mathrm{EcM} \\
\mathrm{SS}>\mathrm{EcM}\end{array}$ & $\begin{array}{c}\mathrm{H}=33.89 \\
\mathrm{p}<0.001 \\
\mathrm{LS}>\mathrm{EcM} \\
\mathrm{SS}>\mathrm{EcM}\end{array}$ & $\begin{array}{c}\mathrm{H}=19.29 \\
\mathrm{p}=0.001 \\
\mathrm{SS}>\mathrm{LS} \\
\mathrm{EcM}>\mathrm{LS}\end{array}$ & $\begin{array}{l}\mathrm{H}=8.76 \\
\mathrm{p}=0.03\end{array}$ & $\begin{array}{c}\mathrm{H}=19.67 \\
\mathrm{p}=0.001 \\
\mathrm{SS}>\mathrm{LS} \\
\mathrm{EcM}>\mathrm{LS}\end{array}$ \\
\hline $\begin{array}{l}\text { Significance of } \\
\text { differences between } \\
\text { fungi and } G \text {. repens (GR) }\end{array}$ & $\begin{array}{c}\mathrm{H}=67.1 \\
\mathrm{p}<0.001 \\
\mathrm{LS}>\mathrm{GR} \\
\mathrm{SS}>\mathrm{GR} \\
\mathrm{EcM}>\mathrm{GR}\end{array}$ & $\begin{array}{c}\mathrm{H}=80.66 \\
\mathrm{p}<0.001 \\
\mathrm{Br}>\mathrm{GR} \\
\mathrm{LS}>\mathrm{GR} \\
\mathrm{SS}>\mathrm{GR} \\
\mathrm{EcM}>\mathrm{GR}\end{array}$ & $\begin{array}{c}\mathrm{H}=141.34 \\
\mathrm{p}<0.001 \\
\mathrm{LS}>\mathrm{GR} \\
\mathrm{SS}>\mathrm{GR} \\
\mathrm{EcM}>\mathrm{GR}\end{array}$ & $\begin{array}{c}\mathrm{H}=51.32 \\
\mathrm{p}<0.001 \\
\mathrm{SS}>\mathrm{GR} \\
\mathrm{EcM}>\mathrm{GR}\end{array}$ & $\begin{array}{c}\mathrm{H}=67.45 \\
\mathrm{p}<0.001 \\
\mathrm{SS}>\mathrm{GR} \\
\mathrm{EcM}>\mathrm{GR}\end{array}$ & $\begin{array}{c}\mathrm{H}=114.53 \\
\mathrm{p}<0.001 \\
\mathrm{SS}>\mathrm{GR} \\
\mathrm{EcM}>\mathrm{GR}\end{array}$ \\
\hline
\end{tabular}

$>$ symbol indicates significant enrichment $(\mathrm{H}$ test $)$

of preferential association of the largest mycoheterotrophic plant known, the orchid Erythrorchis altissima, with a range of wood-decay fungi (Ogura-Tsujita et al. 2018). When mention saprotrophic fungi in green orchids (e.g. Mycena spp. in Anoectochilus or Cymbidium), Selosse et al. (2010) address them as either 'contaminants' or facultative biotrophs with only small mycorrhizal root-colonization ability or endophytes unable to produce true mycorrhizal structures at all. This does not make them unimportant for, according to the same authors, the stage observed can mirror the evolution of mycorrhizal association on its way, so such findings deserve not to be neglected as trifles or experimental artifacts. A range of presumably saprotrophic basidiomycetes repeatedly detected in ectomycorrhizal root tips (Bjerkandera, Mycena, Pleurotus, Xenasmatella etc.) considered as 'parasitic, endophytic or saprotrophic root colonizers rather than true EcM symbionts' due to lack of monophyly with EcM isolates or specific clades formation (Tedersoo \& Smith 2013). This suggestion does not oppose the potential of these fungi recruitment in orchid mycorrhizas for as it was previously mentioned, orchid mycorrhizal fungi are extremely diverse both ecologically and taxonomically and continuous involvement of new fungal lineages into the associations is more than probable.

Due to all data available including the results of our study, it can be proposed that G. repens, like many other green orchids, is quite promiscuous in its mycorrhizal affairs. Besides the 'legitimate', long-lasting and well-acknowledged alliance with rhizoctonial Ceratobasidiaceae, the plant can gain carbon through parasitism on EcM (proved by the sharing of common Russula symbiont with conifers) or on wood or litter decaying fungi that could evolve into mycorrhizal partners of orchids, accompanying the emergence of mixotrophy. This requires further study and more data obtained from contrast in terms of both biotic and abiotic factors habitats.

\section{Isotopic evidence}

The overall results of the $\delta^{13} \mathrm{C}$ and $\delta^{15} \mathrm{~N}$ values for G. repens did not fit the 'classical' mycoheterotrophic model of both $\mathrm{C}$ and $\mathrm{N}$ enrichment compared to autotrophic reference plants. But bearing in mind the retaining photosynthetic ability in the target plant as well as in other mixotrophs (partial heterotrophs) we should expect more complicated and versatile outcome pattern. There are numerous recent data on the phenomenon on mixotrophy indicating its near ubiquitous nature within angiosperms and warning against too straightforward and unequivocal considerations (Gebauer et al. 2016, Selosse et al. 2017). The ${ }^{13} \mathrm{C}$ depletion in $G$. repens compared to autotrophs was observed previously in the similar habitats both with the ${ }^{15} \mathrm{~N}$ enrichment (Hynson et al. 2009). Such pattern is typical for so called initially mycoheterotrophic-autotrophic orchids (IMHOs) that can transfer carbon to their fungal symbionts at adulthood while being parasitic on fungus at early stages of development (Hynson et al. 2013). For G. repens the net carbon transfer to fungus was reported by Cameron et al. (2006) but some issues still remain unclear. At first, the experiment was carried out in a controlled-environment growth chamber, and it is unclear, if it is the case for natural environment. Secondly, as it was pointed out by Hynson et al. 2013, such transfer pattern is typical for the most of green plants involved in mutualistic mycorrhizal associations, and why we do not meet the same effect? The most probable reason is the existence of any specific traits in the transfer processes and in the still unknown (due to absence or rarity of fruibodies) isotope composition of the "rhizoctonia" mycobionts (Selosse et al. 2017), such as Ceratobasidium cornigerum identified in our study. In addition, the above data were obtained using a standard sampling scheme in similar studies, i.e. gathering a pair of upper leaves for analysis. While the analysis of the isotope composition of the 
underground part of $G$. repens revealed significantly higher values of $\delta^{13} \mathrm{C}(-27.5$ and $-24.5 \%$ ), which can reflect the difference between parts of the plant in the sources of carbon nutrition. The rhizome and young shoots contain "heavy" carbon obtained from the mycobiont, whereas the leaves are predominantly enriched with "lighter" products of photosynthesis. Selosse et al. (2017) suggested the same model for orchids from Neottiae tribe.

The mechanism of ${ }^{15} \mathrm{~N}$ increase in IMHOs is still unclear too (Hynson et al. 2013), but for the mixotrophic genus Epipactis ${ }^{15} \mathrm{~N}$ enrichment in plant is strongly driven by ${ }^{15} \mathrm{~N}$ abundance of their mycobionts (Schiebold et al. 2017). $\delta^{15} \mathrm{~N}$ values for $G$. repens were rather variable, but their similarity to those for litter saprotrophic fungi was detected (Table 4). These two groups of organisms inhabit the same substrate, but it cannot be the reason for their similarity in ${ }^{15} \mathrm{~N}$ abundance for fungi possess ability to access far more diverse nitrogen sources (including complex organic compounds) than plants do. Nitrogen supply is one of the vital functions of mycorrhizae in plant performance in boreal biomes (Smith \& Read 2008). The data obtained showed the significant differences between $G$. repens and the surrounding litter $(\mathrm{H}=12.92, \mathrm{p}=0.003)$ along with the corresponding insignificant difference between the target plant and litter decaying fungi.

Therefore, when there are conflicting data on the trophic status of $G$. repens populations occurring from different regions, it become necessary to consider the trophic status of the studied species in particular environmental conditions, taking into account the analysis of the distribution of carbon within different parts of the plant. The detection of the potential heterogeneity of mycobionts in clonal populations as well as differences in the factors affecting them can help to address the issue of different sources of nutrition for mixotrophic plants relative importance.

The confirmation of mixotrophy in G. repens and its relationship with specific symbiosis with EcM-forming and saprotrophic fungi warrant further investigation. At present we can suggest the "cryptic mixotrophy" strategy on the base of similar isotopic pattern and the recruitment of EcM fungi and common with coniferous trees mycorrhizal network formation (Selosse et al. 2017). Particularly, the species compelled to grow in shaded habitats may have a higher dependency on fungal carbon than ones from exposed habitats and thus a mutualistic association with specific fungal partners, more efficient than "rhizoctonia" lineages, is advantageous. The clonal organization of G. repens populations makes the delimitation of an individual within a challenge matching the terrestrial macrofungi problem. By far there are no researchers who attempted to delve into clonal structure of those plants and to observe the transfer processes and mycorrhizal specificity and other aspects of plant-fungal interactions at this angle of view. Non-impossible intraclonal nutrient transfer and the different microhabitats (and different mycobionts) for every single vegetative "individual" can be those particular G. repens features distinguishing this species from other extensively studied orchids and such life-mode probably is a key for its trophic ambiguity. It is the promising prospect for further research along with the above/below-ground parts ${ }^{13} \mathrm{C}$ allocation in at least partially heterotrophic plants vs completely autotrophic ones.

There is still more to discover about the potential mixotrophy of such green orchids associated with "rhizoctonias", probably, in their germination but in addition "inviting" EcM and saprobic fungi at adult stage.

\section{ACKNOWLEDGEMENTS}

The research was financially supported by RFBR, project 16-04-01468 (to E. Malysheva, V. Malysheva, E. Voronina, A. Tiunov, A. Kovalenko and G. Dmitriev - probes sampling, molecular research, stable isotope analysis). Partial financial support by the Russian Science Foundation (RSCF), programme 14-50-00029, to E. Voronina (macrofungal species morphological identification and herbarization) is acknowledged.

\section{LITERATURE CITED}

Agerer, R., J. Christan, C. Mayr \& E. Hobbie 2012. Isotopic signatures and trophic status of Ramaria. Mycological Progress 11:47-59.

Arditti, J. \& A.K.A. Ghani 2000. Tansley review, 110 - Numerical and physical properties of orchid seeds and their biological implications. New Phytologist 145:367-421.

Aronsen, A. \& T. Læssøe 2016. The genus Mycena s.l. In: Fungi of Northern Europe, vol. 5. Narayana Press, Gylling, 373 pp.

Bayman, P. \& J.T. Otero 2006. Microbial endophytes of orchid roots. In: Microbial root endophytes, (B. Schulz, C. Boyle \& T. Sieber, eds), pp. 153-177, Springer, NY.

Bougoure, J.J., M.C. Brundrett \& P.F. Grierson 2010. Carbon and nitrogen supply to the underground orchid, Rhizanthella gardneri. New Phytologist 186:947-956.

Cameron, D.D., J.R. Leake \& D.J. Read 2006. Mutualistic mycorrhiza in orchids: evidence from plant-fungus carbon and nitrogen transfers in the green-leaved terrestrial orchid Goodyera repens. New Phytologist 71:405-416.

Cameron, D.D., I. Johnson, J.R. Leake \& D.J. Read 2007. Mycorrhizal acquisition of inorganic phosphorus by the green-leaved terrestrial orchid Goodyera repens. Annals of Botany 99:831-834.

Cameron, D.D., I. Johnson, D.J. Read \& J.R. Leake 2008. Giving and receiving: measuring the carbon cost of mycorrhizas in the green orchid, Goodyera repens. New Phytologist 180:176-184.

Chen, Y., H. Wang \& S-X. Guo 2012. Isolation and identification of endophytic and mycorrhizal fungi from seeds and roots of Dendrobium (Orchidaceae). Mycorrbiza 22: 297-307.

Currah, R.S. \& C. Zelmer 1992. A key and notes for the genera of fungi mycorrhizal with orchids and a new species in the genus Epulorbiza. Reports of the Tottori Mycological Institute 30:43-59.

Damm, U., R. Baroncelli, L. Cai, Y. Kubo, R. O`Connell, B. Weir, K. Yoshino \& P.F. Cannon 2010. Colletotrichum: species, ecology and interactions. IMA Fungus 1(2):161-165.

Dearnaley, J.D.W., F. Martos \& M-A. Selosse 2012. Orchid mycorrhizas: molecular ecology, physiology, evolution and conservation aspects. In: The Mycota, volume IX Fungal associations, 2nd edition, (K. Esser, ed.), pp. 207230, Springer-Verlag, Berlin.

Fan, L., S.X. Guo, W.Q. Cao, P.G. Xiao \& J.T. Xu 1996. Isolation, culture, identification and biological activity of Mycena orchidicola sp. nov. in Cymbidium sinense (Orchida- 
ceae). Acta Mycologica Sinica 15:251-255.

Gardes, M, \& T.D. Bruns 1993. ITS primers with enhanced specificity for basidiomycetes - applications to the identification of mycorrhizae and rusts. Molecular Ecology 2: 113-118.

Gebauer, G., K. Preiss \& A.C. Gebauer 2016. Partial mycoheterotrophy is more widespread among orchids than previously assumed. New Phytologist 211:11-15.

Girlanda, M., M.-A. Selosse, D. Cafasso, F. Brilli, S. Delfine, R. Fabbian, S. Ghignone et al. 2006. Inefficient photosynthesis in the Mediterranean orchid Limodorum aborvitum is mirrored by specific association to ectomycorrhizal Russulaceae. Molecular Ecology 15:491-504.

Guo, S-X., L. Fan, W.-Q. Cao, J.-T. Xu \& P.-G. Xiao 1997. Mycena anoectochila sp. nov. isolated from mycorrhizal roots of Anoectochilus roxburghii from Xishuangbanna, China. Mycologia 89(6):952-954.

Hajji, L., W. Hlaoua, H. Regaieg \& N. Horrigue-Raouani 2017. Biocontrol potential of Verticillium leptobactrum and Purpureocillium lilacinum against Meloidogyne javanica and Globodera pallida on potato (Solanum tuberosum). American Journal of Potato Research 94(2):178-183.

Harley, J.L. \& E.L. Harley 1987. A check-list of mycorrhiza in the British flora. New Phytologist 105 (Suppl.):1-102.

Hynson, N., K. Preiss \& G. Gebauer 2009. Is it better to give than to receive? A stable isotope perspective on orchid-fungal carbon transport in the green orchid species Goodyera repens and Goodyera oblongifolia. New Phytologist 182 8-11.

Hynson, N.A., T.P. Madsen, M.A. Selosse, I.K.U. Adam, Y. Ogura-Tsujita, M. Roy \& G. Gebauer 2013. The physiological ecology of mycoheterotrophy. In: Mycoheterotrophy: the biology of plants living on fungi, (V.S.F.T. Merckx, ed.), pp. 297-342, Springer, Berlin.

Julou, T., B. Burghardt, G. Gebauer, D. Berveiller, C. Dame$\sin \&$ M.-A. Selosse 2005. Mixotrophy in orchids: insights from a comparative study of green individuals and nonphotosynthetic individuals of Cephalanthera damasonium. New Phytologist 166:639-653.

Katoh, K. \& H. Toh 2008. Recent developments in the MAFFT multiple sequence alignment program. Briefings in Bioinformatics 9:286e298.

Kohout, P., T. Těšitelová, M. Roy, M. Vohník \& J. Jersákova 2013. Mycorrhizal and endophytic fungal communities associated with roots of Pseudorchis albida (Orchidaceae). Fungal Ecology 6:50-64.

Kõljalg, U., K.H. Larsson, K. Abarenkov, R.H. Nilsson, I.J. Alexander, U. Eberhardt, S. Erland et al. 2005. UNITE: a database providing web-based methods for the molecular identification of ectomycorrhizal fungi. New Phytologist 166:1063-1068.

Kõljalg, U., R.H. Nilsson, K. Abarenkov, L. Tedersoo, A.F.S. Taylor, M. Bahram, S.T. Bates et al. 2013. Towards a unified paradigm for sequence-based identification of fungi. Molecular Ecology 22:5271-5277.

Leake, J.R. 1994. The biology of myco-heterotrophic (saprophytic) plants. New Phytologist 127:171-216.

Liebel, H.T., M.I. Bidartondo \& G. Gebauer 2015. Are carbon and nitrogen exchange between fungi and the orchid Goodyera repens affected by irradiance? Annals of Botany 115:251-261.

Lievens, B., S. van Kerckhove, A. Justé, B.P. Cammue, O. Honnay \& H. Jacquemyn 2010. From extensive clone libraries to comprehensive DNA arrays for the efficient and simultaneous detection and identification of orchid mycorrhizal fungi. Journal of Microbiological Methods 80:76-85.
Malysheva, V.F., E.F. Malysheva, E.Yu. Voronina, A.G. Fedosova, N.M. Bibikov, D.S. Kiseleva, A.V. Tiunov \& A.E. Kovalenko 2017. Mycorrhiza of pyroloids (Pyrola rotundifolia, P. media and Orthilia secunda): species composition of symbionts and trophic status of plants. Mikologiya I Fitopatologiya 51(6):350-364 (in Russian with English summary). (Малышева В.Ф., Малышева Е.Ф., Воронина Е.Ю., Федосова А.Г., Бибиков Н.М., Киселева А.С., Тиунов А.В., Коваленко А.Е. 2017. Микориза грушанковых (Pyrola rotundifolia, P. media и Orthilia secunda): состав гриббных симбионтов и трофический статус растений // Микология и фитопатология. Т. 51, № 6. C. 350-364].

McCormick, M.K., D.F. Whigham, D. Sloan, K. O’Malley \& B. Hodkinson 2006. Orchid-fungus fidelity: a marriage meant to last? Ecology 87:903-911.

Mosquera-Espinosa, A.T., P. Bayman, G.A. Prado, A. Gómez-Carabalí \& J.T. Otero 2013. The double life of Ceratobasidium: orchid mycorrhizal fungi and their potential for biocontrol of Rhizoctonia solani sheath blight of rice. Mycologia 105:141-150.

Ogura-Tsujita, Y. \& T. Yukawa 2008. High mycorrhizal specificity in a widespread mycoheterotrophic plant, Eulophia zollingeri (Orchidaceae). American Journal of Botany 95: 93-97.

Ogura-Tsujita, Y., G. Gebauer, H. Xu, Y. Fukasawa, H. Umata, K. Tetsuka, M. Kubota et al. 2018. The giant mycoheterotrophic orchid Erythrorchis altissima is associated mainly with a divergent set of wood-decaying fungi. Molecular Ecology 27(5):1324-1337.

Ownley, B.H., K.D. Gwinn \& F.E. Vega 2010. Endophytic fungal entomopathogens with activity against plant pathogens: ecology and evolution. BioControl 55:113-128.

Peterson, R.L., Y. Uetake \& C. Zelmer 1998. Fungal symbioses with orchid protocorms. Symbiosis 25:29-55.

Peterson, R.L., H.G. Massicotte \& L.H. Melville 2004. Mycorrhizas: Anatomy and Cell Biology. NRC Research Press, Ottawa, 173 pp.

Rasmussen, H.N. 1995. Terrestrial orchids: From seed to mycotrophic plant. Cambridge University Press, Cambridge, 444 pp.

Rasmussen, H.N. 2002. Recent developments in the study of orchid mycorrhiza. Plant \& Soil 244:149-163.

Rasmussen, H.N. \& D.F. Whigham 1993. Seed ecology of dust seeds in situ: a new study technique and its application in terrestrial orchids. American Journal of Botany 80: 1374-1378.

Rinaldi, A.C., O. Comandini \& T.W. Kuyper 2008. Ectomycorrhizal fungal diversity: separating the wheat from the chaff. Fungal Diversity 33:1-45.

Roy, M., C. Gonneau, A. Rocheteau, D. Berveiller, J.-C. Thomas, C. Damesin \& M-A. Selosse 2013. Why do mixotrophic plants stay green? A comparison between green and achlorophyllous orchid individuals in situ. Ecological Monographs 83(1):95-117.

Schiebold, J.M.I., M.I. Bidartondo, P. Karasch, B. Gravendeel \& G. Gebauer 2017. You are what you get from your fungi: nitrogen stable isotope patterns in Epipactis species. Annals of Botany 119:1085-1095.

Schweiger, J.M.I., M.I. Bidartondo \& G. Gebauer 2018. Stable isotope signatures of underground seedlings reveal the organic matter gained by adult orchids from mycorrhizal fungi. Functional Ecology 32(4): 870-881.

Selosse, M-A. \& M. Roy 2009. Green plants that feed on fungi: facts and questions about mixotrophy. Trends in Plant Sciences 14:64-70.

Selosse, M-A., F. Martos, B.A. Perry, M. Padamsee, M. Roy 
\& T. Pailler 2010. Saprotrophic fungal mycorrhizal symbionts in achlorophyllous orchids. Finding treasures among the "molecular scraps"? Plant Signaling \& Behavior 5(4):349-353.

Selosse, M-A., M.F. Bocayuva, M.C.M. Kasuya \& P.E. Courty 2017. Mixotrophy in mycorrhizal plants: extracting carbon from mycorrhizal networks. In: Molecular mycorrbizal symbiosis, (F. Martin, ed.), pp. 451-471, Wiley Blackwell, Hoboken.

Smith, S.E. \& D.J. Read 2008. Mycorrbizal Symbiosis, 3rd edition, Academic Press, NY, 787 pp.

Smith, M.E., A. Gryganskyi, G. Bonito, E. Nouhra, B. Moreno-Arroyo \& G. Benny 2013. Phylogenetic analysis of the genus Modicella reveals an independent evolutionary origin of sporocarp-forming fungi in the Mortierellales. Fungal Genetics and Biology 61:61-68.

Shefferson, R.P., M. Weiss, T. Kull \& D.L. Taylor 2005. High specificity generally characterizes mycorrhizal association in rare lady's slipper orchids, genus Cypripedium. Molecular Ecology 14:613-626.

Shefferson, R.P., D.L. Tavlor, M. Weiß, S. Garnica, M.K. McCormick, S. Adams, H.M. Gray et al. 2007. The evolutionary history of mycorrhizal specificity among lady's slipper orchids. Evolution 61:1380-1390.

Tamura, K., G. Stecher, D. Peterson, A. Filipski \& S. Kumar 2013. MEGA6: Molecular Evolutionary Genetics Analysis Version 6.0. Molecular Biology and Evolution 30:2725-2729.

Tedersoo, L.\& M.E. Smith 2013. Lineages of ectomycorrhizal fungi revisited: foraging strategies and novel lineages revealed by sequences from belowground. Fungal Biology Reviews 27:83-99.
Tsai, W-C., A. Dievart, C-C. Hsu, Y-Y. Hsiao, S-Y. Chiou, H. Huang \& H-H. Chen 2017. Post genomics era for orchid research. Botanical Studies 58(61):1-12.

White, T.J., T. Burns, S. Lee, J. Taylor 1990. Amplification and sequencing of fungal ribosomal RNA genes for phylogenetics. In: PCR protocols. A guide to methods and applications, (M.A. Innis, D.H. Gelfand, J.J. Sninsky, T.J. White, eds), pp. 315-322, Academic Press, San Diego.

Yagame, T., T. Orihara, M-A. Selosse, M. Yamato \& K. Iwase 2012. Mixotrophy of Platanthera minor, an orchid associated with ectomycorrhiza-forming Ceratobasidiaceae fungi. New Phytologist 193:178-187.

Yagame, T., E. Funabiki, E. Nagasawa, T. Fukiharu \& K. Iwase 2013. Identification and symbiotic ability of Psathyrellaceae fungi isolated from a photosynthetic orchid, Cremastra appendiculata (Orchidaceae). American Journal of Botany 100:1823-1830.

Zhao X., J. Zhang, C. Chen, J. Yang, H. Zhu, M. Liu \& F. Lv 2014. Deep sequencing-based comparative transcriptional profiles of Cymbidium hybridum roots in response to mycorrhizal and non-mycorrhizal beneficial fungi. BMC Genomics 15:747.

Zelmer, C.D., L. Cuthbertson \& R.S. Currah 1996. Fungi associated with terrestrial orchid mycorrhizae and protocorms. Mycoscience 37:439-448.

Zimmer, K., N.A. Hynson, G. Gebauer, E.B. Allen, M.F. Allen \& D.J. Read 2007. Wide geographical and ecological distribution of nitrogen and carbon gains from fungi in pyroloids and monotropoids (Ericaceae) and in orchids. New Phytologist 175:166-175. 